\title{
Morphological and Yield Traits of Cowpea (Vigna unguiculata L. Walp.) under Integrated Nutrient Management
}

\author{
Vineet Singh $^{1}$, Amit Kumar Singh ${ }^{1}$, Maneesh Kumar Singh ${ }^{1 *}$, \\ Tushar Raghuvanshi ${ }^{2}$ and Umesh Singh ${ }^{2}$
}

\author{
${ }^{1}$ Department of Botany, Udai Pratap Autonomous College, Varanasi-221002 (U.P.), India \\ ${ }^{2}$ Division of Crop Improvement, Indian Institute of Vegetable Research, PB- 01, PO- Jakhini \\ (Shahanshahpur), Varanasi- 221305 (U.P.), India \\ *Corresponding author
}

\begin{tabular}{|c|c|}
\hline \multicolumn{2}{|r|}{ A B S T R A C T } \\
\hline & \multirow{6}{*}{$\begin{array}{l}\text { To study the impact of reduced dose of chemical fertilizer and its combination with } \\
\text { biofertilizer on morpho-physiological and biochemical traits of cowpea cultivar "Kashi } \\
\text { Kanchan (VRCP-4)", field experiments were conducted during summer seasons at Udai } \\
\text { Pratap Autonomous Collage, Varanasi, Uttar Pradesh, India. The total seven treatments } \\
\text { with control }\left(\mathrm{T}_{1} \text { to } \mathrm{T}_{7}\right) \text { comprise different sources of organic and inorganic fertilizers, i.e. } \\
\text { Phosphate solubilising bacteria (PSB), recommended dose of NPK and Azotobactor were } \\
\text { endeavoured. From the evaluation of morphological and yield related attributes, the } \\
\text { experimental findings revealed that highest plant height }(\mathrm{cm}) \text {, number of leaf } / \text { plant, } \\
\text { nodes } / \text { plant, length of internode }(\mathrm{cm}) \text {, pod length }(\mathrm{cm}) \text { were found noticeable in treatment } \\
\text { NPK }(100: 50: 50 \mathrm{~kg} / \mathrm{ha})+\text { Azotobacter }(5 \mathrm{~kg} / \mathrm{ha})\left(\mathrm{T}_{5}\right) \text {, whereas number of pod/plant, } \\
\text { number of seed } / \text { pod, average pod weight }(\mathrm{g}) \text {, TSS and yield } / \text { plant }(\mathrm{kg}) \text { were observed in } \\
\text { the treatment NPK }(100: 50: 50 \mathrm{~kg} / \mathrm{ha})+\mathrm{PSB}(7.5 \mathrm{~kg} / \mathrm{ha}) \text {. From the investigation of ascorbic } \\
\text { acid, the highest content was observed in treatment of fertilizer combination NPK } \\
(100: 50: 50 \mathrm{~kg} / \mathrm{ha})+\text { Azotobacter }(5 \mathrm{~kg} / \mathrm{ha})+\mathrm{PSB}(7.5 \mathrm{~kg} / \mathrm{ha}) \text {. }\end{array}$} \\
\hline Keywords & \\
\hline $\begin{array}{l}\text { Azotol } \\
\text { fertiliz } \\
\text { NPK, }\end{array}$ & \\
\hline Article Info & \\
\hline $\begin{array}{l}\text { Accepted: } \\
27 \text { September } \\
\text { Available Onl } \\
10 \text { October } 20\end{array}$ & \\
\hline & \\
\hline
\end{tabular}

\section{Introduction}

Cowpea (Vigna unguiculata L. Walp., asparagus bean/snake bean/yard long bean) is an imperative legume vegetable and pulse crop predominantly grown in the arid and sub-arid zones of the tropical world. It is used as vegetables, pulse, fodder and green manure. It is often grown as a green manure for soil improvement and cover crop to control the soil erosion particularly in the areas having distressed soil erosion crisis.

The tender green leaves are an important food source in Africa and are used as vegetable like spinach. Immature green pods are used as vegetable and being mixed with other vegetables. Green cowpea seed are boiled as a fresh vegetable or may be canned or frozen.

Some unusual utilization of cowpea includes uses in terms of vegetable mixture, baking powder of biscuits and legume starch. Since cowpea is a leguminous crop, it has the capacity to fix atmospheric nitrogen through symbiotic nitrogen Fixation, being a short duration crop it fits well in various multiple and intercropping system. After picking of 
pods cowpea plants may be used as green fodder or as green manure.

The variety Kashi Kanchan is emerging as popular substitutes of local cultivars in large scale. But in farmer's field the green pod yield is far below than the actual yield potential of the variety. Traditionally the crop is raised using primary nutrients supplied through straight fertilizers without use of micronutrients or biofertilizers. This zone soil is characterized by acidic in $\mathrm{pH}$ and low in available nitrogen and phosphorus due to light in texture and leaching of bases in rainfall. It is several times documented that nitrogen in cowpea to soil stimulated the development of green colour in leaves and help in stem elongation and branching, whereas phosphorus is regarded as the pioneer plant nutrient since it is needed by the leguminous crop for rapid and healthy root development which latter on becomes helpful in nodulation by rhizobium bacteria. Sufficient supply of Phosphorus to plant hasten the maturity and increases the rate of nodulation and pod development, it is also an important constituent of vital substances like phospholipids, nucleic acid and certain enzymes and also takes part in enzyme fixing and releasing process. Azotobacter is a genus of usually motile, oval or spherical bacteria that form thick-walled cysts and may produce large quantities of capsular slime. They are aerobic, free-living soil microbes which play an important role in the nitrogen cycle in nature, binding atmospheric nitrogen, which is usually inaccessible to plants, and releasing it in the form of ammonium ions into the soil (Gandorn et al., 1998, Martynick 2003).

Phosphate solubilising Bacteria (PSB) are group of beneficial bacteria capable of hydrolysing organic and inorganic phosphorus from insoluble compound (Chen et al., 2006). Organic matter, farmyard manure, vermicompost, oil cakes of different oil seeds like castor, neem etc. incorporation of organic residues of proceeding crop in the field and also serves as a source of organic nutrients. Keeping the above facts in mind the present investigation have don to evaluate the effect of integrated nutrient management on morphological and yield attributes of cowpea.

\section{Materials and Methods}

The present investigation was conducted under natural field condition with cowpea cultivar "Kashi kanchan (VRCP-4)" at Udai Pratap Autonomous Collage, Varanasi during summer season. The average values of temperature and humidity during the experiment period were, maximum temperature $36.4^{\circ} \mathrm{C}$, minimum temperature $23.3^{\circ} \mathrm{C}$; maximum $\mathrm{RH} 71 \%$, minimum $\mathrm{RH}$ $25 \%$. Cowpea seed were sown during the month of the April in $20 \times 60 \mathrm{~cm}$ spacing under well ploughed field in RBD manner.

The effect of various treatment applied were observed at 30, 45 and 60 days after sowing. Treatments are $\mathrm{T}_{1}$ - Control, $\mathrm{T}_{2}-$ Azotobactor (5kg/ha), $\mathrm{T}_{3}-$ Phosphate Solubilising Bacteria (PSB) - (@7.5 kg/ha), T4 -NPK-(@100:50:50 $\mathrm{kg} / \mathrm{ha}), \quad \mathrm{T}_{5} \quad$-NPK-(@ 100:50:50kg/ha) + Azotobactor (@5kg/ha), $\quad \mathrm{T}_{6} \quad$-NPK(@100:50:50kg/ha) + PSB (@7.5 kg/ha), T 7 NPK-(@100:50:50kg/ha) + Azotobactor (@5kg/ha) + PSB (@7.5 kg/ha), FYM - 100 $\mathrm{kg} / \mathrm{ha}$ applied at the time of field preparation.

During the experiment, at harvest five plant samplings were carried out per treatment (total of 15 plants) were taken for study plant height, number of leaves/plant, Number of nodes, Length of internodes, pod length, number of pod/plant, number of seed/pod, yield/plant $(\mathrm{kg})$.

T.S.S. ( ${ }^{0}$ Brix) - The total soluble solids (TSS) of the fruits was measured by taking the juice of the green pod on digital hand refractometer and values were expressed in terms ${ }^{0}$ Brix. 
Ascorbic acid (mg/100g) -The Vitamin "C" the cowpea pods were measured with by the standard method of vitamin 'C' as suggested by Ranganna S., 1986.

\section{Results and Discussion}

Extensive variations were recorded in various traits by the application of integrated nutrient management. Regarding the Plant height of cowpea, maximum were recorded in the treatment $\mathrm{T}_{5} \quad(\mathrm{NPK} \quad(100: 50: 50 \mathrm{~kg} / \mathrm{ha})+$ Azotobacter $5 \mathrm{~kg} / \mathrm{ha}$ ) at 30,45 and 60 DAS. It was measured $34.5 \mathrm{~cm}$ after 30 days of sowing, $44.9 \mathrm{~cm}$ at $45 \mathrm{DAS}$, whereas, after 60 DAS it was $59.7 \mathrm{~cm}$ (Fig.1a). Similar results were also noticed regarding the number of leaves per plant after 30, 45 and 60 days after sowing. In the treatment $\mathrm{T}_{5}$ at $30 \mathrm{DAS}$, number of leaves were found 18.7, whereas, it was 26.5 at 45 DAS and likewise, 46.8 after 60 days of sowing (Fig.1c). Singh and Thakur (2007) were also found the maximum plant height number of leaves and yield of onion plant with the application of $\mathrm{N}_{2} 75 \mathrm{~g}$ with Azospirillum @ 400 gm/200 seeding roots. Again in the combination of NPK + Azotobacter $\left(\mathrm{T}_{5}\right)$, higher number of nodes per plant observed, it was 9.5, 14.3 and 18.3 at 30, 45 and 60 DAS respectively (Fig.1b). Length of internodes were observed after 30 and 60 days of sowing and it was maximum $7.5 \mathrm{~cm}$ at $30 \mathrm{DAS}$ in $\mathrm{T}_{5}$ and after 60 days 15.8 $\mathrm{cm}$ in treatment $\mathrm{T}_{4}$ (Fig.1d). Jayaraman et al., (2008) noticed that combined application of FYM (25t/ha), $75 \%$ recommended dose of NPK $(45: 37,5.30 \mathrm{Kg} / \mathrm{ha})$ and vermicompost also produced higher number of laterals inter nodal length and number of leaves in Snake gourd.

The observation related to pod length at harvesting stage in three randomly selected plant was $34.03 \mathrm{~cm}$ in $\mathrm{T}_{5}$, while the minimum $18.97 \mathrm{~cm}$ in $\mathrm{T}_{1}$ (control). Significant differences were noted regarding the number of pod 37.7 in $\mathrm{T}_{6}$, whereas, minimum 11.2 in control. Maximum number of seed per pod at the harvesting time was recorded 13.4 in $\mathrm{T}_{6}$ i.e. application of FYM @ 10t/ha + NPK + PSB, followed by $T_{7}$ and $T_{5}$, while the minimum number of seed per pod was recorded in control 4.33. Pod weight per plant at the harvesting stage was recorded maximum $15.2 \mathrm{~g}$ in the treatment $\mathrm{T}_{6}$. Treatment $\mathrm{T}_{6}$ and $\mathrm{T}_{7}$ was found to be significant with each other, minimum was recorded in control (10.03 g). At maturity maximum total soluble solid was noticed 2.8 in the application of FYM@10t/ha + NPK + Azotobacter, it was again found minimum in control (1.2) (Table 1).

Table.1 Effect of Integrated nutrient Management on morphological and yield traits on cowpea

\begin{tabular}{|c|c|c|c|c|c|c|c|c|}
\hline S.No. & Treatments & $\begin{array}{l}\text { Pod length }(\mathrm{cm}) \\
\text { harvesting }\end{array}$ & $\begin{array}{l}\text { number of } \\
\text { pod/plant }\end{array}$ & $\begin{array}{l}\text { number of } \\
\text { seed/pod }\end{array}$ & $\begin{array}{l}\text { yield } / \mathrm{pl} \\
\text { ant }(\mathrm{kg})\end{array}$ & $\begin{array}{l}\text { Average } \\
\text { pod wt. (g) }\end{array}$ & $\begin{array}{l}\text { TSS } \\
\left({ }^{0} \text { Brix }\right)\end{array}$ & $\begin{array}{l}\text { Ascorbic Acid } \\
\text { (mg/100g.) }\end{array}$ \\
\hline $\mathrm{T}_{1}$ & Control & 18.97 & 11.17 & 4.33 & 10.03 & 8.33 & 1.2 & 10.5 \\
\hline $\mathrm{T}_{2}$ & Azotobacter $(5 \mathrm{~kg} / \mathrm{ha})$ & 22.27 & 12.8 & 6.27 & 11.73 & 10.67 & 1.9 & 12.5 \\
\hline $\mathrm{T}_{3}$ & PSB (7.5kg/ha) & 22.42 & 12.5 & 6.5 & 11.2 & 10.8 & 1.8 & 12.8 \\
\hline $\mathrm{T}_{4}$ & NPK (100:50:50kg/ha) & 29.77 & 25.73 & 9.57 & 13.87 & 11.5 & 1.82 & 12.9 \\
\hline $\mathrm{T}_{5}$ & $\begin{array}{l}\text { NPK }(100: 50: 50 \mathrm{~kg} / \mathrm{ha})+ \\
\text { Azotobacter }(5 \mathrm{~kg} / \mathrm{ha})\end{array}$ & 31.33 & 32.2 & 11.13 & 14.57 & 12.3 & 2.1 & 14.9 \\
\hline $\mathrm{T}_{6}$ & $\begin{array}{l}\text { NPK }(100: 50: 50 \mathrm{~kg} / \mathrm{ha})+ \\
\text { PSB }(7.5 \mathrm{~kg} / \mathrm{ha})\end{array}$ & 34.03 & 37.7 & 13.37 & 16.13 & 15.17 & 2.8 & 14.9 \\
\hline $\mathrm{T}_{7}$ & $\begin{array}{l}\text { NPK }(100: 50: 50 \mathrm{~kg} / \mathrm{ha})+ \\
\text { Azotobcater }(5 \mathrm{~kg} / \mathrm{ha})+\mathrm{PSB} \\
(7.5 \mathrm{~kg} / \mathrm{ha})\end{array}$ & 33.2 & 35.57 & 11.63 & 15.63 & 14.23 & 2.23 & 15.8 \\
\hline $\mathrm{SEm} \pm$ & & 0.84 & 0.88 & 0.3 & 0.43 & 0.36 & 0.04 & 0.31 \\
\hline $\mathrm{CD}_{(0.05)}$ & & 2.61 & 2.73 & 0.94 & 1.33 & 1.12 & 0.13 & 0.96 \\
\hline
\end{tabular}


Fig.1 Shows effect of integrated nutriment management on various morphological traits.

1(a) Plant height (cm), 1(b) Nodes per plant, 1(c) Number of leaf per plant,

1(d) Length of internode $(\mathrm{cm})$

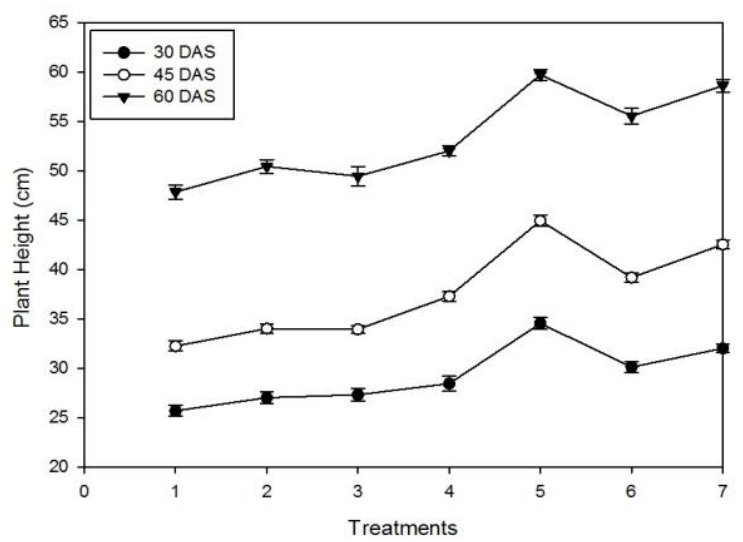

Fig.1 (a)

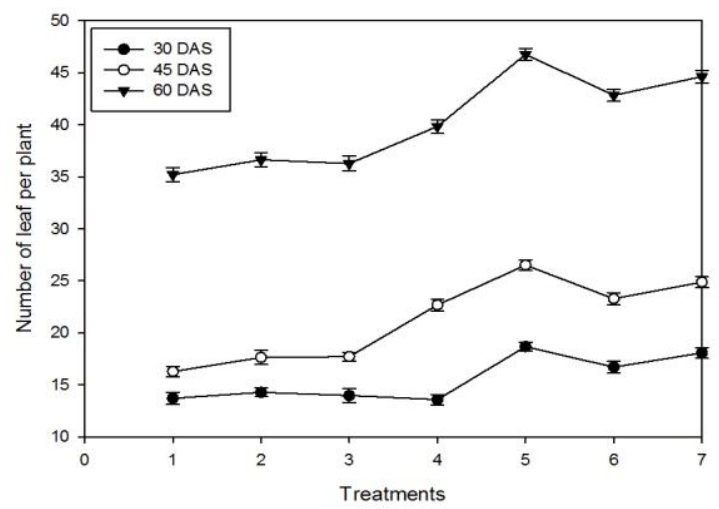

Fig. 1 (c)

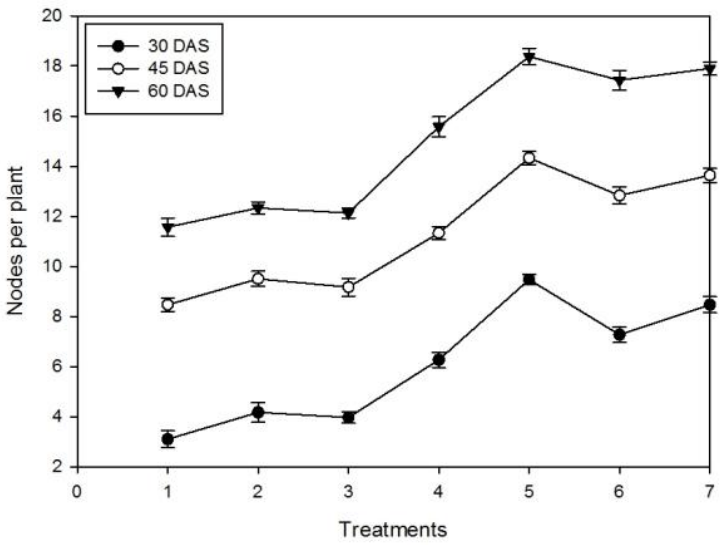

Fig. 1 (b)

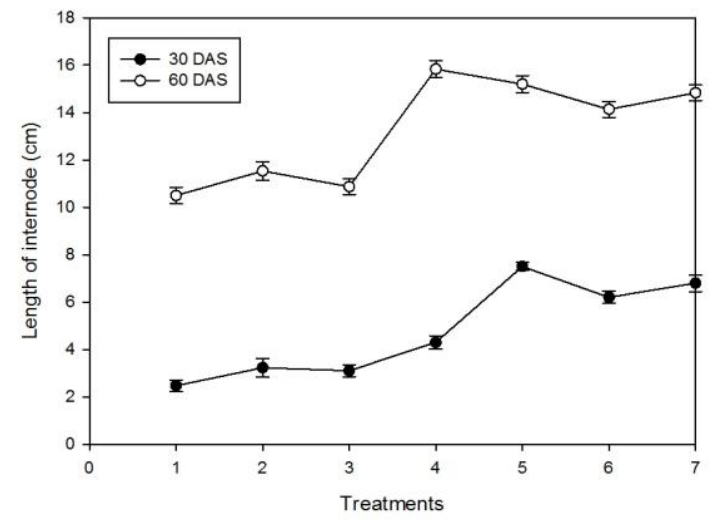

Fig.1 (d)

1- $\mathrm{T}_{1}$-Control, 2- $\mathrm{T}_{2}$-Azotobactor - (5kg/ha), 3- $\mathrm{T}_{3}$ - Phosphate Solubilising Bacteria (PSB) - (@7.5 kg/ha), 4- $\mathrm{T}_{4}$ NPK-(@100:50:50kg/ha), 5-T 5 -NPK-(@100:50:50kg/ha)+Azotobactor (@5kg/ha),6-T 6 -NPK-(@ 100:50:50kg/ha) +PSB (@7.5 kg/ha), 7- T7-NPK-(@100:50:50kg/ha)+Azotobactor (@5kg/ha)+PSB (@7.5 kg/ha), FYM - 100 $\mathrm{kg} / \mathrm{ha}$

Ascorbic acid is the widely known compound used as an antioxidant and the most effective compound increasing the tolerance of plants to oxidative stresses. The results obtained by using the transgenic plants and mutants, confirmed the role of ascorbic acid in oxidative stress or scavenging free-oxyradicals (Smith et al., 1989). In the present investigation maximum ascorbic acid content was observed in treatment $\mathrm{T}_{7} 15.8 \mathrm{mg} / 100 \mathrm{~g}$, which is 1.5 fold higher than the control. In term of yield, it differs significantly from the control. $\mathrm{T}_{6}$ (NPK (100: 50: $\left.50 \mathrm{~kg} / \mathrm{ha}\right)$, PSB (7.5kg/ha) shows maximum yield $16.1 \mathrm{~kg}$ while in control $37.81 \%$ reduction in yield were noted (Table 1). Thamizh and Nanja (1998) in potato, Bahadur and Manohar (2001) in Okra, Bahadur et al., (2006) in Chinese cabbage, Jadav et al., (2008) in okra also studied the nutrient uptake and yield influenced by integrated plant nutrient supply.

Bairwa et al., (2009) also reported that number of fruit, fruit yield/per plant, fruit weight, length of fruit and its thickness with the application of neem cake $69 \mathrm{~kg} / \mathrm{ha}+$ 
vermicomposed 10kg/ha + Azotobacter + PSB $+60 \mathrm{~kg} / \mathrm{ha}$ with recommended dosed of NPK.

In conclusion, for sustainably increasing agriculture productivity, research based recommendation must be focus on integrated use of organic manures, bio-fertilizer along with synthetic fertilizer rather than increase the rate of recommended synthetic fertilizers, that provide high yields, grain quality and adequate soil fertility. Our experimental findings showed that cowpea productivity can be enhanced through integrated nutrient management in the presence of biofertilizers. Our study reflects those integrated use of chemical fertilizers, organic manures and azotobacter, assume greater significance of improving efficiency of chemical fertilizers in soil health or soil biodiversity, developing the biological activities, increasing the environmental hygiene, conservation and supporting the ecology. Integrated use of organic and inorganic fertilizer also increased grain protein content compare to use of chemical fertilizer alone. Adoption of integrated nutrient management in combination with recommended inorganic fertilizers would bring beneficial results for profitability in cowpea cultivation. The practice will encourage inclusion of cowpea in crop sequence.

\section{Acknowledgements}

The authors are thankful to the Head, Department of Horticulture, Udai Pratap (Autonomous) College, Varanasi, for providing necessary facilities to conduct this research work.

\section{References}

Bahadur, A., and Manohar, R.K. 2001. Response of okra to biofertilizers. Veg. Sci. 28 (2): 197-198.

Bahadur, Anant; Singh, J., Upadhyay, A.K.
Singh, K.P. and Rai, Mathura 2006. Effect of organic amendment and bio fertilizers on growth yield and quality attributes of Chinese cabbage (Brassica pekinensis) Indian I. Hort. 76 (10): 596598.

Bairwa, H.I., Shukla, A.K., Mahawer, L.N., Kaushik, R.A., Shukla, K.B. and Ameta K.D. (2009). Response of integrated nutrient management on yield, quality and physio-chemical characteristics of okra cv. Arka Anamika, Ind. J. of Horticulture. Vol. 66 (3010-314).

Chen, Y.P., Rekha P D, Arun A B, Shen F T, and Lai young W A November 2006. Phosphate solubilizing bacteria are able to produce organic acid that are the main reason of inorganic phosphate. Phosphate solubilizing bacteria from subtropical soil and their tricalcium phosphate solubilizing abilities.

Gandorn, V., Gupta R D and Bhardwaj K K R 1998. "Abundance of Azotobacter in great soil groups of North West Himalayas. Journal of the India Society of Soil Science46 (3):379-383.

Jadav, Kajal A., Patil, A.S. and Deshmukh, B.B. Mane 2008. Nutrient uptake and yield of okra okra (Abelmoschus esculentus (L.) Moench.) As influenced by integrated plant nutrient supply. $A n$ Asian Journal of Soil Science, 3(3): 106-108.

Jayaraman, N., Anburani, A. and Suchindra, R.R. 2008. Growth Characters influenced by various organic manures in snake gourd var. Co- 2. Veg. Sci.35 (1): 95-96.

Martyniuk, S., and Martniuk M 2003. "Occurrence of Azotobacter spp. In some Polish Soils" Polish Journal of Environmental Studies 12 (3) 371-374.

Rangana, S., 1986. Handbook of analysis and quality control for fruit and vegetable products. Second Ed. Tata McGraw-Hill Pub. Com. Ltd., New Delhi. 
Singh, D.R., and Thakur, K.S. 2007. Effect of nitrogen and Azospirillum inoculation on growth and yield of onion (Allium cepa L.) Har. J. Hort. Sic, 36 (1\& 2): 153-155.

Smith, I.K., Vierheller TL, Thorne CA 1989. Properties and functions of glutathione reductase in plants. Physiol Plant 77: 449- 456

Thamizh, V.R., and Nanjan, K. 1988. Biofertilizer for potato in the Nilgiris. South Indian Hortic. 46 (3 and 4): 211213.

\section{How to cite this article:}

Vineet Singh, Amit Kumar Singh, Maneesh Kumar Singh, Tushar Raghuvanshi and Umesh Singh. 2017. Morphological and Yield Traits of Cowpea (Vigna unguiculata L. Walp.) under Integrated Nutrient Management. Int.J.Curr.Microbiol.App.Sci. 6(10): 3402-3407.

doi: https://doi.org/10.20546/ijcmas.2017.610.399 